\title{
A study of the 1 and 2 January 2010 sea-storm in the Ligurian Sea
}

\author{
F. Pasi ${ }^{1,2}$, A. Orlandi ${ }^{1,2}$, L. F. Onorato ${ }^{3}$, and S. Gallino ${ }^{3}$ \\ ${ }^{1}$ CNR-IBIMET, Firenze, Italy \\ ${ }^{2}$ Consorzio LaMMa, Sesto F. no, Italy \\ ${ }^{3}$ Meteo Hydrological Center, Genova, Italy
}

Received: 27 December 2010 - Revised: 18 April 2011 - Accepted: 18 April 2011 - Published: 12 May 2011

\begin{abstract}
During the last days of 2009 and the first days of 2010, a wide and deep low pressure system over Western Europe generated a very extended and strong southerly pressure gradient on the whole Western Mediterranean Sea with a resulting very rough to high sea state. Over the Ligurian Sea (North Western Mediterranean) the resulting sea state was a combination of a very tuned (in both frequency and direction) swell coming from the south-west, with nearly oceanic peak wave period, and a broader north-westerly wind sea with shorter period. This kind of sea state, not extreme in terms of significant wave height, caused unusual widespread damages to Ligurian coastal structures.

In this study, authors investigated the structure of such a combined sea state by analysing numerical weather prediction outputs coming from atmospheric and wave models and comparing them with data coming from ondametric buoys and meteorological stations located in the Ligurian Sea area. As a result, it was found that the forecasting model chain almost correctly predicted the wave height in a first phase, when the sea state was only due to the first south-westerly swell peak, while significantly underestimated the combined sea state, when also the second north-westerly wind sea developed and interacted with the first one.

By analysing the structure of directional wave spectra forecasted by the operational wave model and measured by the buoys, authors have attempted to find out the reasons for model deficiencies in forecasting the time evolution of significant parameters characterising the sea state.
\end{abstract}

\section{Introduction}

Sea storms in the Mediterranean basin are a quite common event especially during winter months (Littmann, 2000). In particular, over the Lion Gulf (due to frequent Mistral outbreaks) and the Genoa Gulf (one of the most cyclogenetic areas of the Mediterranean, Trigo et al., 2002), several episodes of significant wave height (hereafter SWH) above $3 \mathrm{~m}$ (Medatlas, 2004) are recorded each year. A climatological study performed at the Regional Weather Service of Liguria Region (Onorato et al., 2006 and internal report), analysing the data recorded by the Ventimiglia buoy (here-

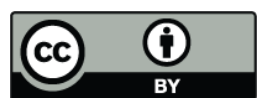

Correspondence to: F. Pasi (pasi@lamma.rete.toscana.it) after XXM, Fig. 1) during the period 1998-2010, found that sea-storms with SWH greater than $4.3 \mathrm{~m}$ are correlated with a mean wave period (hereafter MWP) of about $8.4 \mathrm{~s}$.

The present study is focused on an interesting sea-storm that occurred in the first days of 2010 with an unusual damage producing capability over the Ligurian coasts. Damages were widespread and affecting a wide portion of the Ligurian coast, comprising the most western tip, very rarely affected by such events (see red line in Fig. 1). The Ligurian Regional Government reported the interruption of railway and "Aurelia" main road and the damaging of various harbor docks and several commercial activities, for a total of more than 20 millions of euro. The Ligurian Regional Weather Service on 1 January 2010 morning issued a level 1 warning (the lowest of 3 levels), which "a posteriori" must be considered underestimated. 


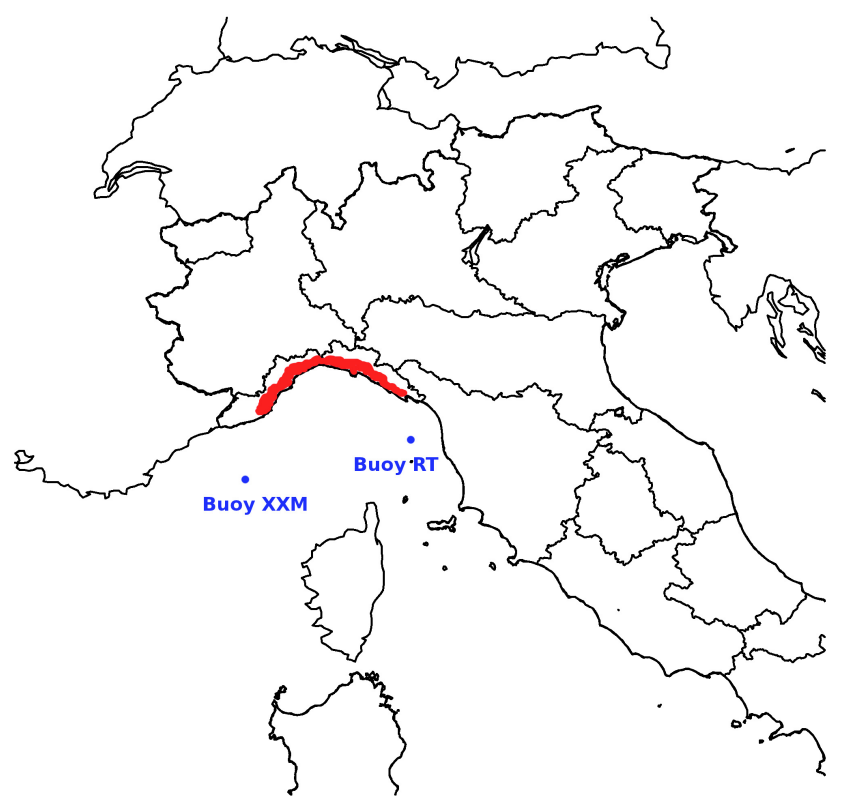

Figure 1. Detailed map of the Ligurian sea and coastlines, where red line describes the area of main coastal damages. Blue dots show the location of the two moored buoys used in the study, the Ventimiglia (XXM) and Tuscany Region one (RT).

Trough a detailed analysis of the evolution of the sea state occurred during the event, authors will try to answer the following questions: (1) among the swell characteristics which one was mainly responsible for such a severe impact over the Ligurian coast? (2) had the forecasters enough information to make a "good job" or did they need something else to estimate the risky forthcoming events?

The present work is organized as follows: Sect. 2 contains a detailed description of the sea-storm with the support of several data collected by ondametric buoys. Section 3 , the most articulated one, contains: a brief description of the operational modeling chain in use by the two Regional Meteorological Weather Services of Liguria and Tuscany (in charge of issuing warnings), a discussion of the models' performances in terms of average fields and a general discussion of the sea-storm dynamic trough a spectral analysis approach. Finally, in Sect. 4, some conclusions and suggestions for the forecasters' operational practice are drawn.

\section{Description of the event}

On 29 December 2009 a deep (around $980 \mathrm{hPa}$ ) low pressure system, initially located in the Atlantic off the Irish coasts, begun to extend its influence to the Western Mediterranean Sea with a pressure thalweg. During 30 and 31 December 2009 the low pressure system moved south-eastward across France towards the Lion Gulf, filling up to $990 \mathrm{hPa}$ : an extended gale-force south-westerly pressure gradient was present over the majority of Western Mediterranean basin.
On 1 January 2010 the low pressure moved quite rapidly from the Lion Gulf (990 hPa at 00:00 UTC) to the Genoa Gulf (988 hPa at 06:00 UTC), then passing to the Adriatic Sea (992 $\mathrm{hPa}$ at 18:00 UTC) and finally moving over the Balkans (990 hPa at 00:00 UTC on 2 January 2010). As a consequence the south-westerly pressure gradient in the eastern part of Western Mediterranean Sea (see Fig. 2a) experienced first an intensification, then a westerly to northwesterly veering and finally a rapid decrease on 2 January 2010 second half of the day (see Fig. 2b).

An interesting feature of the wind field is that, while in the western part of the Mediterranean Sea south-westerly and westerly gale force winds persisted for more than $48 \mathrm{~h}$, in the area of Genoa Gulf light winds dominated. The XXM buoy, located in open sea (see Fig. 1), recorded fluctuating gentle to moderate south-westerly winds (10-17 kt) until 00:00 UTC on 2 January 2010, increasing to strong or near gale winds (25-35 kt) only after the west, north-west veering and persisting until 15:00 UTC on 2 January 2010 (see Fig. 3). Also coastal wind gauge stations confirmed the presence of a light wind regime, with sustained wind speed values only after the rotation to north on 2 January 2010 (not shown).

For what concerns the sea-storm characteristics, data from the XXM buoy allow the individuation of three different phases (see Fig. 3). The first phase that goes from 12:00 UTC on 31 December 2009 to 18:00 UTC on 1 January 2010 was characterised by an increase in both SWH and MWP (from 2 to $4 \mathrm{~m}$ and from 6 to $11 \mathrm{~s}$ respectively). The corresponding sea state can be ascribed to the arrival of a swell coming from a very distant generating area, probably located in Western Mediterranean Sea (south of Balearic Islands). In fact, a wave group with a period of about $10 \mathrm{~s}$ propagates at a speed of about $25 \mathrm{kt}$ and covers the distance between the generating area and the XXM buoy (about 400 nautical miles) in $16 \mathrm{~h}$. Considering that the XXM buoy recorded the first peak in SWH values at 15:00 UTC on 1 January 2010, the generation time of this peak should be around 00:00 UTC on 1 January 2010. This seems in good correlation with models' outputs forecasting a $10 \mathrm{~s}$ period, $6 \mathrm{~m} \mathrm{SWH}$ sea state in generation south of Balearic Islands (not shown).

The second phase, which goes from 18:00 UTC on 1 January to 06:00 UTC on 2 January 2010, was characterised by SWH and MWP remaining almost constant at values of $4 \mathrm{~m}$ and $11 \mathrm{~s}$ respectively. The third phase, which goes from 06:00 UTC to 18:00 UTC on 2 January 2010, was characterized by an irregular decrease of SWH and a more regular decrease of MWP. Each of these sea-storm's phase show its own peculiarities and will be discussed more in detail in the next paragraphs.

For what concerns coastal damages the most effective of the three phases was the second one (between 18:00 UTC on 1 January to 06:00 UTC on 2 January 2010). 

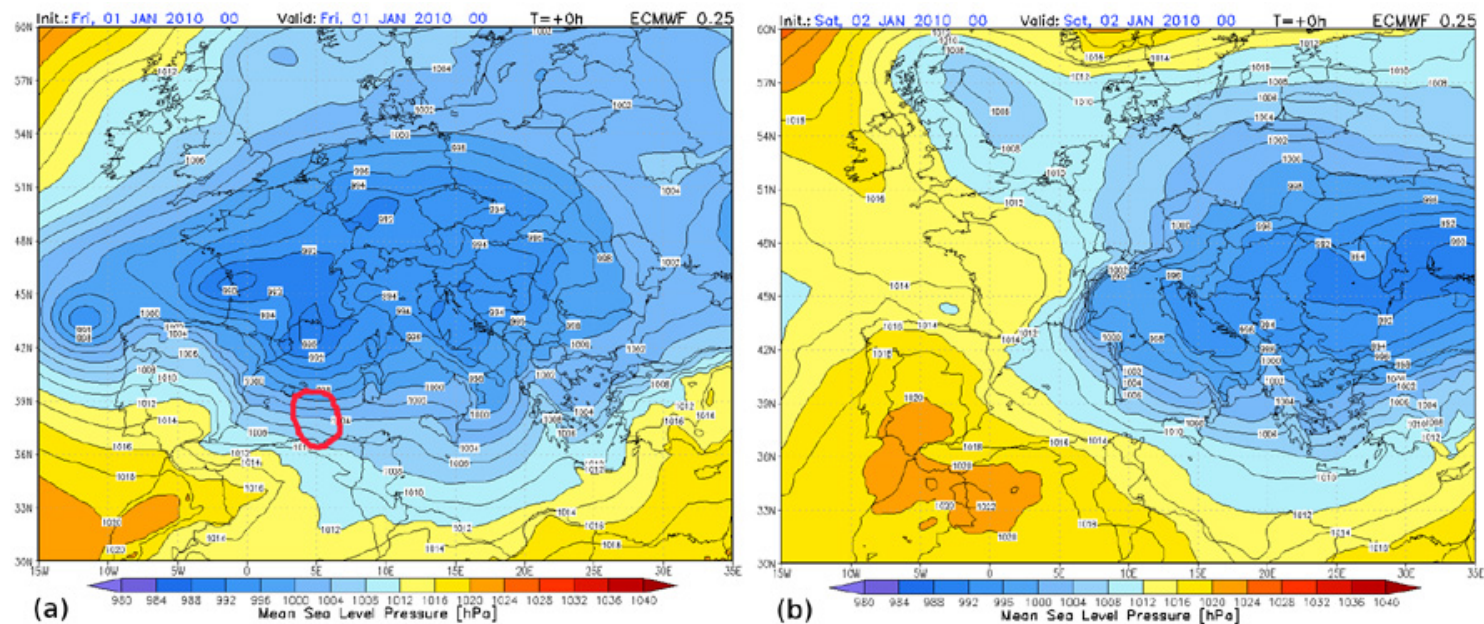

Figure 2. Mean Sea Level Pressure (hPa) from ECMWF analysis (bluish colors for low pressure values). Left panel (a) 00:00 UTC on 1 January 2010 with main low pressure system over France and Lion Gulf at $990 \mathrm{hPa}$, strong westerly baric gradient in the Central Mediterranean Sea. Red Circle indicates supposed generation area of swell component arrived in Ligurian Sea on 1 January 2010 early afternoon. Right panel (b) 00:00 UTC on 2 January 2010 with main low pressure system over Balkans at $990 \mathrm{hPa}$ and strong north-westerly baric gradient over Central Mediterranean Sea.

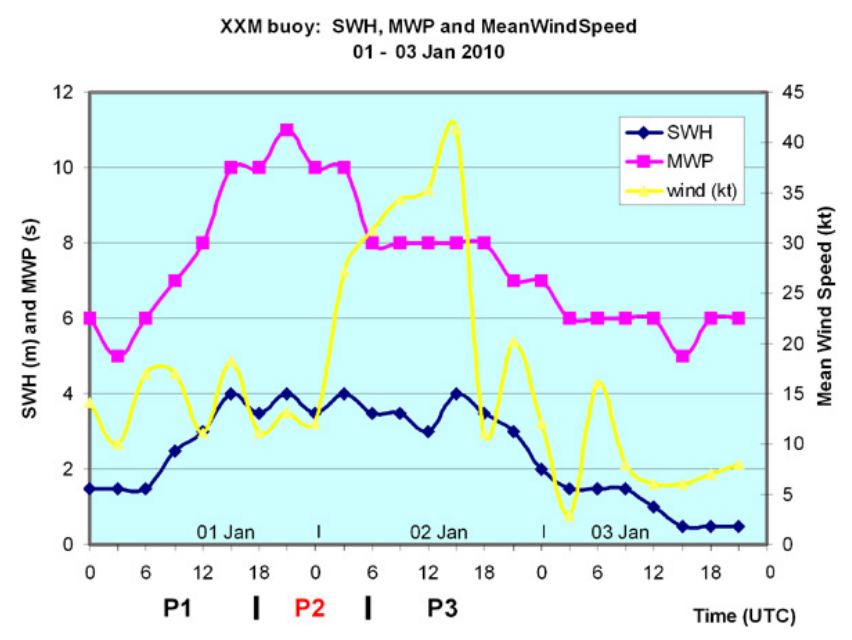

Figure 3. 1-3 January 2010 (hours in UTC) XXM buoy time-serie. Blue line indicates SWH (m), purple line MWP (s), yellow line $10 \mathrm{~m}$ wind speed (kt). P1 to P3 refers to the sea-storm different phases. $\mathrm{P} 2$ (in red) is the most damaging one.

Only considering SWH values, the total amount of damages reported (see Sect. 1) is quite inexplicable because: (1) sea-storms with SWH of around $4 \mathrm{~m}$ do happen several times a year (about 30 cases were observed at XXM buoy in the last $12 \mathrm{yr}$ ); (2) sea-storm phase 3 was not damaging despite SWH was still around $4 \mathrm{~m}$ (as in phase 2); (3) the wind regime in the area was light and surely not recognised as a dangerous one. Nevertheless, if the $12 \mathrm{yr}$ statistics of MWP occurrence at XXM buoy are analysed, the actual $11 \mathrm{~s}$ value is the largest recorded.
Another consideration, which will not be discussed in detail in this article, but that is surely worth to mention was a coincident high astronomic tide that clashed with the strong barometric high tide (mean sea level pressure was quite low) causing record sea level rise up to $60 \mathrm{~cm}$ during the seastorm peak (Ray et al., 2011; and Padman and Erofeeva, 2004). This contributed to coastal wave penetration and might also explain why local reporters visually estimated the wave height, when breaking at coast at more than $6 \mathrm{~m}$ (Wang et al., 2008).

\section{Modeling results}

\section{The operational chain}

The modeling chain applied here to investigate the sea-storm details is the one implemented and used operationally at the Regional Weather Service of Tuscany region, namely the Laboratory for Meteorology and environmental Modeling (Consorzio LaMMA, http://www.lamma.rete.toscana.it) and is composed by a meteorological model and a wave model running in cascade. The former is the atmospheric model WRF-NMM (http://www.wrf-model.org, Janiic, 2003 and Skamarock et al., 2005), at a resolution of $0.12^{\circ}$ with initial and boundary conditions from NCEP-GFS (T382L64) at $0.5^{\circ}$ resolution. The latter is the WW3 third generation spectral wave model (http://polar.ncep.noaa.gov/waves/ wavewatch/wavewatch.shtml, Tolman et al., 2002; Tolman, 2006, 2009; Komen et al., 1994; Janssen, 2007), running over the whole Mediterranean Sea at the same resolution of the atmospheric model. Atmospheric initial and boundary conditions for the present study was taken from the 

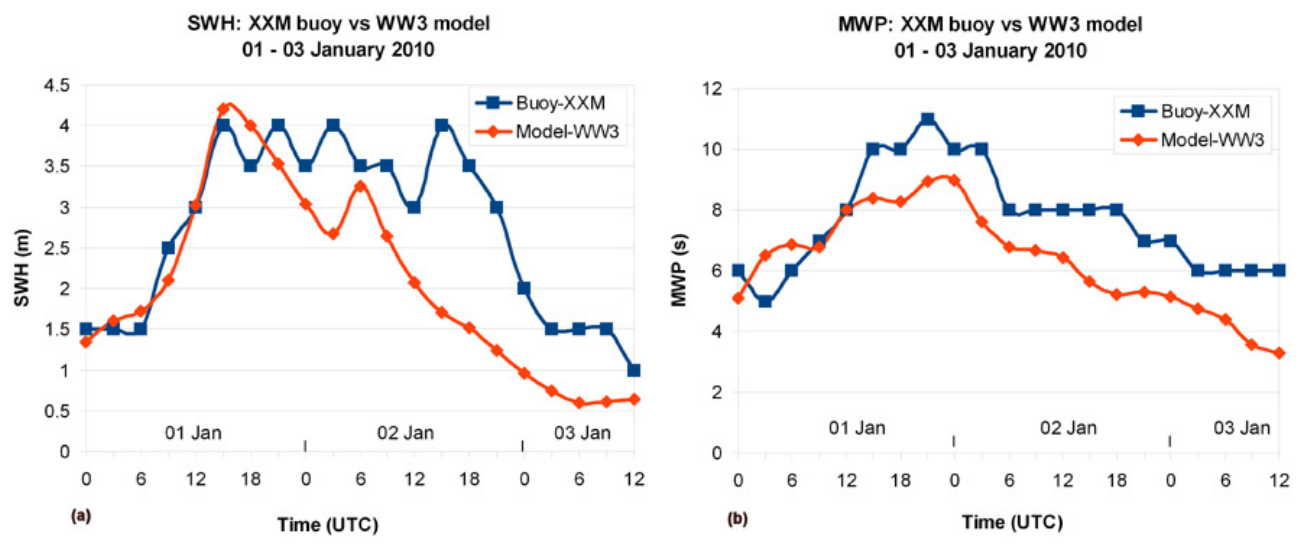

Figure 4. Comparison between XXM buoy (blue line) and ww3 model (orange). Time series for 1-3 January 2010 (hours in UTC). Left panel (a) SWH (m), right panel (b) MWP (s).

1 January 2010, 00:00 UTC operational GFS run, as a consequence the maximum sea-storm peak (18:00 UTC on 1 January to $06: 00$ UTC on 2 January 2010) is at the +18 to $+30 \mathrm{~h}$ of model forecast.

\subsection{Average fields}

Average quantities like SWH and MWP are the most commonly used by forecasters in the operational practice when elaborating sea state bulletins and emergency warnings for navigation (Niclasen et al., 2011) and coastal structures (US Army CEM, http://chl.erdc.usace.army.mil/cem). Figure $4 \mathrm{a}$ and $\mathrm{b}$ show a comparison between model outputs (SWH and MWP) and corresponding observed data at XXM buoy. For sea-storm phase 1 (until 18:00 UTC on 1 January 2010), the wave model was quite good in forecasting SWH (matching both time phase and intensity), but underestimated MWP (forecasted at $8 \mathrm{~s}$ against the measured $10 \mathrm{~s}$ ). In terms of the sea-storm character, limiting the analysis to such model data, the forecaster could be brought to think to a sea state more dominated by wind sea, or a sea state due to a swell being weaker or coming from a nearer place than it has been in reality. For sea-storm phase 2 (18:00 UTC on 1 January to 06:00 UTC on 2 January 2010) the wave model underestimated both SWH and MWP, even though MWP is forecasted slightly growing. This last feature is compatible with a sea-storm that is getting more and more swelldominated. Model predicted MWP reaches its maximum between 21:00 UTC on 1 January and 00:00 UTC on 2 January 2010, with corresponding SWH of 3.5 and $3 \mathrm{~m}$, against measured values of $4 \mathrm{~m}$. Again the wave model is probably underestimating the intensity of the swell component of the sea state, coming from the distant generation area (Balearic Islands). This is probably due to a not perfect representation of the wind field over the sea-storm fetch. This, in turn, might depend either on a general underestimation of the wind speed or to a not correct wind direction representation (e.g. a more westerly than south-westerly component) or both. These aspects should be investigated more deeply with a more general (in the sense of the area involved) verification against observed data. Sea-storm phase 3 is the less accurate predicted one, with a strong underestimation of SWH and MWP. In this phase winds veered from the northern direction (North-West, North) and increased to gale-force (as confirmed by a second observed SWH peak of $4 \mathrm{~m}$ at around 15:00 UTC on 2 January 2010). This rapid increase is not predicted by the model and should be investigated more deeply.

\subsection{Analysis of wave directional spectra}

The analysis of the directional wave spectrum allows the most complete investigation of predicted sea states (Orlandi et al., 2008; Bradbury et al., 2007). Figure 5a and b show model energy spectra of the predicted sea state during phase 2 and phase 3 of the sea-storm at XXM buoy.

In this representation, the color palette is indicative of the wave energy density $\left(\mathrm{m}^{2} \mathrm{~s} \mathrm{rad}^{-1}\right)$ and the meteorological convention is used to

specify wind direction as that from which the wind blows. On the north-west (north-east) radius the period (the frequency) is reported with a graduation that increases (decreases) moving away from the plot center. On the southwest radius the wave length graduation (in meters) is reported, while on the south-east radius the group velocity graduation (in knots) is shown. Super imposed blue arrow is the local mean wind direction, green arrow is the mean wave direction and red arrow is the wave peak direction.

The possible sea state scenario that can be reconstructed on the basis of such model data, is described below.

Figure 5a valid for 00:00 UTC on 2 January 2010, corresponds to the sea-storm phase 2 (widespread coastal damages). This is an unimodal spectrum, which is a sea state with a single south-westerly component. The main features of this sea state are: (1) a light wind (blue arrow) coming from 

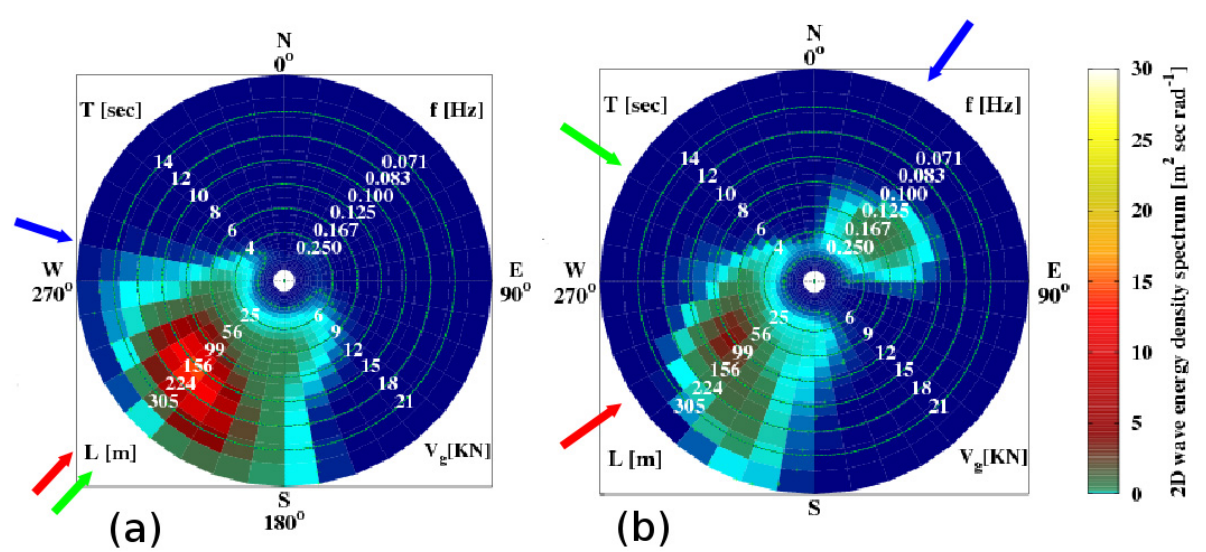

(b)

Figure 5. Wave energy spectrum for ww3 model at XXM buoy location. Color is proportional to wave energy $\left(\mathrm{m}^{2} \mathrm{srad} \mathrm{rad}^{-1}\right)$. Blue arrow indicates the mean wind direction, green arrow the mean wave direction and red arrow the wave peak direction. Left panel (a) valid for 00:00 UTC on 2 January 2010 (sea-storm phase 2). Right panel (b) valid for 15:00 UTC on 2 January 2010 (sea-storm phase 3).

the west, north-west (not generating a relevant wave component); (2) nearly coincident mean and peak wave direction (from the south-west, green and red arrows); (3) mean and peak angular spreading coincident and very narrow (around $\left.12^{\circ}\right)$; (4) a very intense and tuned peak at about $11 \mathrm{~s}$ of period. Looking carefully, the structure of the peak is asymmetric and seems to be composed of two sub components: one weaker satellite component, more southerly and with a period of near $12 \mathrm{~s}$ (probably coming from a farther more intense generation area), and the other dominant and narrower in frequency component, from south-west, with a slightly smaller period (near 11s). These two peaks components might correspond to two different phases of the low pressure development and or movement, with maxima winds producing two different distant wave generation areas between Balearic and Sardinia Islands. All these features indicate that the predicted sea state (even though slightly underestimated) consisted of a very tuned (in both direction and frequency) and powerful swell coming from the south-west with nearly oceanic period (not usual in the Mediterranean Sea and especially in the Genoa Gulf), totally uncorrelated with the local weak wind (blue arrow), which is no relevant wind sea components are present.

Figure $5 \mathrm{~b}$ refers to 15:00 UTC on 2 January 2010, which is sea-storm phase 3 (not causing coastal damages), when a second SWH maximum was registered (about $4 \mathrm{~m}$ ). This is a 3 peaks energy spectrum with the south-westerly component still being the most energetic, but now lower than in phase 1 and with lower peak period (about $8 \mathrm{~s}$ ).

Main features of this sea state are: (1) a short period (around $6 \mathrm{~s}$ ) not very energetic sea state from the north-east caused by a moderate to strong north-easterly wind (blue arrow); (2) a persistent, but lower, main peak (red arrow) from the south-west with little (but increasing) angular spreading; (3) a still present satellite component from the south, southwest, probably older (longer period) and less energetic that

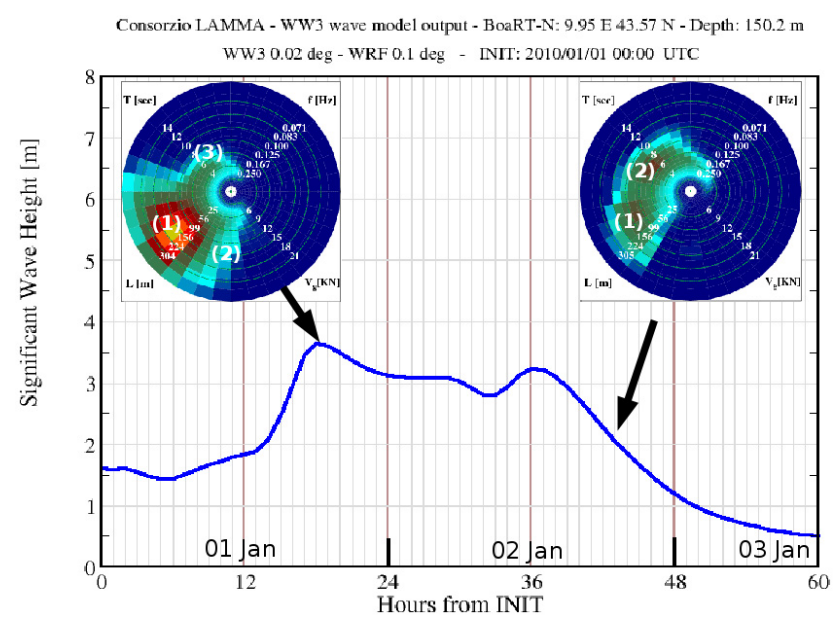

Figure 6. SWH (m) wave model forecast time-serie for the RT buoy location valid for the period from 00:00 UTC on 1 January to 12:00 UTC on 3 January 2010. Upper left: directional wave spectrum forecast for 18:00 UTC on 1 January as indicated by the black arrow. Upper right: same as upper left, but for 12:00 UTC on 2 January 2010 .

the main one; (4) a very wide total mean angular spreading $\left(90^{\circ}\right)$ resulting in a total mean wave direction from the north-west (green arrow, not realistic being the average of the whole spectrum).

These considerations indicate that sea-storm phase 3 mean SWH was the combination of at least two nearly opposite sea states (one from the south-west the other from the northeast), and that the main south-westerly peak of the sea-storm was less energetic, less tuned and, more relevant, with lower peak period than in phase 2 . These are probably among the characteristics that might explain why sea-storm in phase 3 was less effective in penetrating and damaging the coast than in phase 2. 

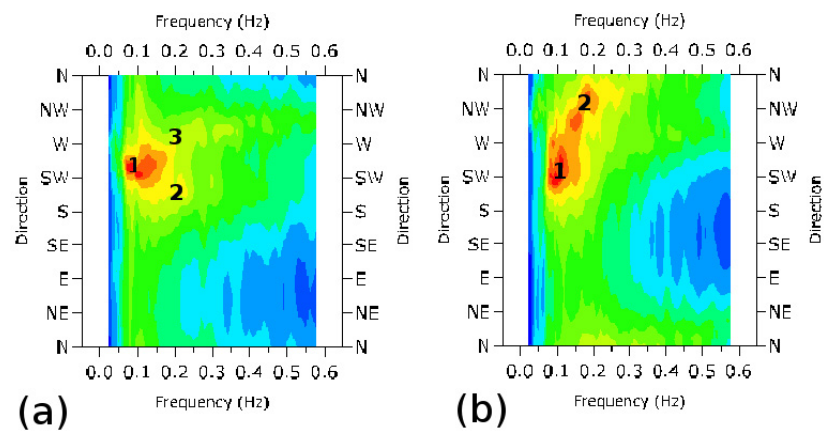

Figure 7. RT buoy directional wave energy spectrum. Colour is proportional to wave energy $\left(\mathrm{m}^{2} \mathrm{~s} \mathrm{rad}^{-1}\right)$. Super imposed numbers (black) indicate the main spectral peaks (see text). Left panel (a) 12:00 UTC on 1 January 2010 (arrival of the distant swell). Right panel (b) 19:00 UTC on 2 January 2010 (decaying phase). The graphical format of these plots is different from the model's directional plots because buoy data are processed by a proprietary software of Datawell (Waves@21) that allows only this kind of representation.

A further analysis has been performed by comparing model spectra with those measured by a Datawell MKIII directional wave buoy installed by Tuscany Region north of Gorgona Island (RT-buoy, see Fig. 1). In Fig. 6 model's forecasted time-series of SWH together with two model wave spectra are shown. The first spectrum is valid for 18:00 UTC on 1 January 2010 , i.e. the time of the first peak due to the arrival of the distant swell. A comparison with the corresponding spectrum recorded by the RT-buoy (Fig. 7a) show a good agreement of the main features: a dominant peak (1) from the south-west (swell), a minor component from the south (2) and an even minor component from the north-west (3), which is correlated with the local wind direction. Also the values of the period of the 3 peaks are in fair agreement while $\mathrm{SWH}$ values are slightly overestimated (model $3.5 \mathrm{~m}$, buoy $2.9 \mathrm{~m})$

The second spectrum is valid for 19:00 UTC on 2 January 2010, i.e. during the decaying phase. A comparison with the corresponding spectrum recorded by the buoy (Fig. 7b) shows in both spectra two peaks in general agreement: a swell peak from south-west (1), a peak from northwest correlated with the wind (2). The model underestimate the peak from the south-west and the corresponding value of SWH is significatively lower than the recorded one (model $2.1 \mathrm{~m}$, buoy $3.7 \mathrm{~m}$ ).

\section{Conclusions}

In this work, the authors investigated a sea-storm that occurred during the first days of year 2010 in the Western Mediterranean Sea. The peculiarity of this event was that a not unusual sea-storm (more than 3 times per year for similar SWH values) caused unusual widespread damages to a wide portion of the Ligurian coast. With data collected at two ondametric buoys and ground stations (not shown) and with numerical outputs from an operational met-ocean modelling chain (WRF+WW3), the sea-storm sea state structure has been investigated. As a result, it was found that the seastorm evolution could be divided into three different phases. Only during phase 2 relevant coastal damages was produced. The sea state of this sea-storm phase was characterised by an extreme (relatively to the Mediterranean wave climate) peak wave period of $11 \mathrm{~s}$ (the only occurrence in the last $12 \mathrm{yr}$ ).

In the second part of the study, operational forecasts were used to investigate more deeply the sea-storm characteristics. The pro and cons of assuming an average versus a full spectral approach is briefly described in both phase 2 and 3 of the sea-storm. It comes out that the full spectral approach is by far more complete allowing a better understanding of the sea state structure. As a consequence, it is shown why phase 3 of the sea-storm, even though characterized by the same SWH values of phase 2 , was not as effective in producing coastal damages. Finally it is suggested the adoption of a full spectral approach also in the operational met-ocean forecasting practice.

From the point of view of models' performance, it is necessary to further investigate and improve the operational models chain. Even though correctly representing the overall evolution of a very rough to high sea state in the open sea over Western Mediterranean Sea, the chain was not able to correctly extend the intensity of the swell to the target area (both for SWH and MWP).

The influence of local bathymetry might have also played an important role in the waves' effectiveness to penetrate the coast (local observer reported 5 to $6 \mathrm{~m}$ height waves). This should be addressed with specific high resolution modeling (e.g., SWAN, Booij et al., 1999), which is under development at Consorzio LaMMA. During this further investigation the possible influence of coupled astronomic and barometric tides at coast should be taken into account, as well.

Acknowledgements. This work is part of a long-term cooperation between the Meteo-hydrological service of Liguria Region (www.meteoliguria.it) and the Regional Weather Service of Tuscany region (www.lamma.rete.toscana.it). We acknowledge Meteo France for the XXM buoy data.

Edited by: F. Stel

Reviewed by: M. Sioutas and another anonymous referee SC $\mid$ nat $^{\mathbf{T}} \begin{aligned} & \text { The publication of this article is sponsored } \\ & \text { by the Swiss Academy of Sciences. }\end{aligned}$ 


\section{References}

Booij, N., Ris, R. C., and Holthuijsen, L. H.: A third-generation wave model for coastal regions. Model description and validation, J. Geophys. Res., 104(C4), 7649-7666, 1999.

Bradbury, A. P., Mason, T. E., and Poate, T.: Implications of the spectral shape of wave conditions for engineering design and coastal hazard assessment - evidence from the english channel, 10th International Workshop on Wave Hindcasting and Forecasting and Coastal Hazard Symposium North Shore, abstract no. J5, Oahu, Hawaii, 11-16 November 2007.

Janjic, Z. I.: A Nonhydrostatic Model Based on a New Approach, Meteorol. Atmos. Phys., 82, 271-285, 2003.

Janssen, P. A. E. M.: Progress in ocean wave forecasting, J. Comp. Sci., 227, 3565-3572, 2007.

Komen, G. J., Cavalieri, L., Donelan, M., Hasselmann, K., Hasselmann, S., and Janssen, P. A. E. M.: Dynamics and modelling of ocean waves, Cambridge Book online, Online ISBN: 9780511628955, Hardback ISBN: 9780521470476 , Paperback ISBN: 9780521577816, Book doi:10.1017/CBO9780511628955, 1994 (Online Publication Date: January 2010).

Littmann T.: An empirical classification of weather types in the Mediterranean basin and their interrelation with rainfall, Theor. Appl. Climatol., 66, 161-171, 2000.

Medatlas Group: Wind and Wave Atlas of the Mediterranean Sea, W.E.A.O. Research Cell, 2004.

Niclasen, B. A., Simonsen, K., and Magnusson, A. K.: Wave forecasts and small-vessel safety: A review of operational warning parameters, Mar. Struct., in press, 2011.

Onorato, L., Gemelli, P., and Gallino, S.: A supervisionate classification approach of south-westerly wind regime causing severe weather over the Gulf of Genoa, 6th Annual Meeting of the EMS/6th ECAC, P0095 POSTER EMS2006-A-00386, 2006.
Orlandi, A., Pasi, F., Onorato, L. F., and Gallino, S.: An observational and numerical case study of a flash sea storm over the Gulf of Genoa, Adv. Sci. Res., 2, 107-112, doi:10.5194/asr-2107-2008, 2008.

Padman, L. and Erofeeva, S.: A Barotropic Inverse Tidal Model for the Arctic Ocean, Geophys. Res. Lett., 31, L02303, doi:10.1029/2003GL019003, 2004.

Ray, R. D., Egbert, G. D. and Erofeeva, S. Y.: Tide predictions in shelf and coastal waters: status and prospects, in: Coastal Altimetry, edited by: Vignudelli, S., Kostianoy, A. G., Cipollini, P., and Benveniste, J., 1st Edn., XII, 566 pp., ISBN 978-3-64212795-3, Springer-Verlag, 2011.

Skamarock, W. C., Klemp, J. B., Dudhia, J., Gill, D. O., Barker, D. M., Wang, W., and Powers, J. G.. A description of the Advanced Research WRF Version 2, NCAR Tech Notes-468+STR, 2005.

Tolman, H. L.: A third-generation model for wind waves on slowly varying, unsteady and inhomogeneous depths and currents, J. Phys. Ocean., 21, 782-797, 2006.

Tolman, H. L.: User manual and system documentation of wavewatch III version 3.14, NOAA/NWS/NCEP/MMAB Technical Note 276, 2009.

Tolman, H. L., Balasubramaniyan, B., Burroughs, L. D., Chalikov, D. V., Chao, Y. Y., Chen, H. S., and Gerald, V. M.: Development and implementation of wind generated ocean surface wave models at NCEP, Wea. Forecast., 17, 311-333, 2002.

Trigo, I. F., Bigg, G. R., and Davies, T. D.: Climatology of Cyclogenesis Mechanisms in the Mediterranean, Mon. Weather Rev, 130, 549-569, 2002.

Wang, S., McGrath, R., Hanafin, J., Lynch, P., Semmler, T., and Nolan, P.: The impact of climate change on storm surges over Irish waters, Ocean Model., 25, 83-94, 2008. 